Volume 6 Issue 4, December 2019

Nationally Accredited Journal,

Decree No. B/4130/E5/E5.2.1/2019

\title{
Concept Of Criminal Liability Of Notary Law In Deed Making Based On Perjury
}

\author{
Ailina Rahmanita Fauzi $^{1}$, Iin Khaeriyatun Ni'mah ${ }^{2}$ and Sri Endah \\ Wahyuningsih $^{3}$
}

\begin{abstract}
Purpose research These are 1) To analyze the concept of criminal responsibility notary law in the deed that is based on false information. 2) To analyze the legal consequences of the deed notary Based on False Information.The method used by researchers is Empirical Juridical (socio legal research)and specification in this study were included descriptive analysis. Even the sources and types of data in this study are primary data obtained from field studies with an interview with a notary in Grobogan. And secondary data obtained from the study of literature. This study uses qualitative data analysis Based on the results of research that 1) Notaries can not be held criminal liability associated with the manufacture of the deed (partijnakten) based on false information, and can not meet the crime of counterfeiting element formulation in Article 266 paragraph (1) in conjunction with Article 55 paragraph (1) of the Criminal Code. 2) However, the notary can be held criminal liability against relaas deed or deed of officials (ambtelijke akten) if deliberate or careless notary make a fake deed to the detriment others. That made base on notary deed against false information does not in itself result in the deed null and void. The aggrieved party to the existence of the deed as it should file a civil suit to the court to cancel the deed.

Keywords : Concept of Law; Criminal Responsibility; Notary; Deed; Specification False
\end{abstract}

\section{Introduction}

Notary institutions are social institutions known as "notary", arising from the needs of people who want the existing civil and / or going on between them. The notary institution with the powers assigned by the public (openbaar gezag), to where and when the law demands it or desired by the community, make written evidence that has authentic power. ${ }^{4}$

Notary in running Professionals providing services to the public should behave according to the rules. This is important because the Notary duties of office is not simply - his own personal interests, but also for the benefit of society, as well as an obligation to ensure the correctness of the deed he had done, because it is a Notary demanded more sensitive, honest, fair, and transparent in order to ensure hold on objectives and obligations of all parties directly involved in the manufacture of an authentic deed. In carrying out his duties of a Notary must cling to the Notary office code of ethics, because without it the dignity of professionalism will be lost and no longer has the confidence of the public.

\footnotetext{
${ }^{1}$ Student of Master of Notary Law, Faculty of Law, Sultan Agung Islamic University, Semarang, email: ailinarahmanita@gmail.com

${ }^{2}$ Student of Master of Law, Faculty of Law, Sultan Agung Islamic University, Semarang, email: khaeriyatuni@gmail.com

${ }^{3}$ Lecturer of Faculty of Law Unissula, email: endah.w@unissula.ac.id

${ }^{4}$ GHS Lumban Tobing, 1982, Rule Notary, Erland, Jakarta, p. 2
} 
According to Komar Andasasmita, so that every Notary have sufficient knowledge breadth and depth as well as good skills in designing, composing, creating a variety of authentic deeds, the structure of language, technical, juridical neat, good and true, as well as the expertise needed anyway honesty, sincerity and properties or views in accordance with the actual situation. ${ }^{5}$

In the development of law in Indonesia, often seen and there is a difference between the provisions applicable in practice and what is prescribed in the theory. Sometimes things or new development that can not be / have not been able to be followed by the development of legal instruments in Indonesia, as seen in the practice of notaries and public officials of land deed (PPAT) in the manufacture of authentic deeds. Notaries are public officials who have the authority to make the authentic act on all deeds, agreements and determination are ordered by general rules or requested by the parties to a deed. ${ }^{6}$

In practice, sometimes the parties or client provide information / statement is not true (false) to the notary. Notaries do not know that the information / statements are statements / false statement. Notary pour statement / statement in the form of a notarial deed. Furthermore, others who feel aggrieved questioned the notary deed, even the notary reported to law enforcement authorities on the basis of a criminal act. In such cases, the problem that arises is whether the notary can be held accountable under criminal law?

If the notary committed a crime, then the course can be held accountable under criminal law. This is in line with the view of Hans Kelsen that the concepts related to legal obligations is the concept of legal liability, ie a person legally responsible for an act he or a person's particular bear legal responsibility. ${ }^{7}$

Because the question of criminal responsibility is related to human or person, it is thus not something that is absolute and eternal of all time, but it is relative and inconsistent. Therefore the principle culpability / principle of error must also be in accordance with the views of people about moral values and the values of common decency where the laws are made and implemented, and this fit the paradigm of constructivism that reality was actually a plural, diverse and relatively. Therefore, the formulation of the problem of criminal liability is also not absolute cooperation between communities from one another, because among other people who have different views on moral values and the values of common decency adopted in society. ${ }^{8}$

Things that become problems associated with the task of making a notarial deed notary is based on the information / false statement. Real question is, can the notary requested criminal liability associated with a deed that is based on false information? Related to the issue, UUJN not regulate criminal acts related to the notary office. Thus,

\footnotetext{
${ }^{5}$ Komar Andasasmita, 1981, Komar Andasasmita, 1981, Notaris Dengan Sejarah, Peranan, Tugas Kewajiban, Rahasia Jabatannya, Sumur, Bandung, p.14

${ }^{6}$ Sudikno Mertokusumo, 2004, Arti Penemuan Hukum Bagi Notaris, Renvoi, p. 49

${ }^{7}$ Kelsen, Hans, 2007, General Theory Of Law and State, Teori Umum Hukum Dan Negara, Dasar-Dasar IImu Hukum Normatif Sebagai IImu Hukum Deskriptif-Empirik, Alih Bahasa oleh Soemardi, BEE Media Indonesia, Jakarta, p. 81.

${ }^{8}$ Sri Endah Wahyuningsih, 2018, Model Pengembangan Asas Hukum Pidana Dalam KUHP Berbasis Nilai-Nilai Ketuhanan Yang Maha Esa, Fastindo, Semarang, p. 60
} 
Volume 6 Issue 4, December 2019

Nationally Accredited Journal,

Decree No. B/4130/E5/E5.2.1/2019

if there is a criminal offense related to the duties of a notary, then apply the provisions of the Criminal Code.

Based on the above problems, the purpose of this study as follows: To analyze the legal concept of criminal responsibility of the notary in the deed that is based on false information; and to analyze the legal consequences of the deed notary based on False Information.

\section{Research methods}

The method research approach that researchers use is legal Juridical Empirical (sociolegal research). ${ }^{9}$ This research is descriptive research that aims to paint a picture of the state of things on certain areas and at certain times. This research by its nature is an analytical descriptive study aimed at presenting the results of research are detailed as possible about the above issues, as well as the obstacles encountered and what legal action can be taken to resolve the problem. Even the sources and types of data in this study are primary data obtained from field studies with an interview with a notary in Grobogan. And secondary data obtained from the study of literature. This study uses qualitative data analysis

\section{Discussion}

\subsection{Concept of Criminal Liability Notary law Deed in Making Based on Fake Specification}

Criminal act is an act which by a rule of law is prohibited and punishable provided that in the meantime remember that prohibition is addressed to act, (ie a situation or incident caused by the behavior of people), while the criminal threat addressed to those that caused the incident. Between prohibition and criminal threats there is a close relationship, therefore, between the incident and the person causing the incident, any strong relationship which cannot Separate each other's. Therefore, for any criminal act must any elements:

- Deeds (human);

- That meet in the formulation of legislation (the formal requirements), and;

- Against the law (a material requirement).

Related the criminal responsibility of a notary, the question that arises is, in terms of how a notary may be asked of criminal responsibility if he makes a certificate that is based on false information? The answer to this question, of course, must refer to the applicable regulations. Referring to the current regulations, it is known that a notary can be held criminal liability in the case of a deed that is based on false information, and rules that are related to the above problems is Article 263 paragraph (1), 264

\footnotetext{
${ }^{9}$ Zainudin Ali, 2009, Metode Penelitian Hukum, Sinar Grafika, Jakarta, p 105
} 
paragraph (1) to-1, or 266 paragraph (1) of the Criminal Code jo. Article 55 paragraph (1) of the Criminal Code. While UUJN provision does not regulate criminal offense committed by a notary.

So in this case cannot be said to be a notary dader or perpetrators. ${ }^{10}$ Article 266 paragraph (1) of the Criminal Code, it can be seen that become elements, namely:

- Whoever;

- Input command false information into an authentic deed;

- With a view to taking or have someone else wear the deed as if his statement in accordance with the truth;

- The act was to cause harm. Then the culprit in accordance with

Article 55 paragraph (1) to 1 of the Criminal Code, namely:

- they are doing;

- they were told to do;

- they followed in deeds.

If a Notary declared as "people who do have to put false information into an authentic deed...", is an impossible thing done by a Notary, because:

- deed made in the form of a deed partie which made by notary based on demand of the parties to take notes or write down everything matters discussed by the parties with regard to legal action.

- "People are told to do", according to Article 55 paragraph (1) to 1 of the Criminal Code, that is they are doing all the criminal elements, which means:

- if it is associated with the position of a notary who made the certificate partie, is a POINTS excessive and can not be done, because it's possible the notary will send the parties to put false information in an authentic deed made by the notary, but it is the desire of the parties who told notary make the deed.

- if Notary, declared a "people told to do send false shortages of composure put into an authentic deed ...", is also an impossible thing done by a Notary, due to each the parties come to the Notary to make such deed, and it is an agreement for the two sides to set forth in the deed, as well as a strange thing also notaries as competent authorities are those who have the will commit criminal acts sent to the two sides to put false information on a certificate they want together, because the information that is in deed an agreement the two parties.

Under Article 1 (1) and Article 15 states that notaries authorized UUJN make authentic deed. Then, notaries in performing their duties for the achievement need protection and guarantee legal certainty, so that in their duties stipulated in the provisions UUJN notary, so UUJN as lex specialists of the Criminal Code, and form relationships with the client notary must be associated with the Article 1869 of Civil Law. Where a deed for not in power or not spoken or because of a disability in its form, cannot be treated as an authentic deed, however, have the power as a writing under the hand if it is signed by the stakeholders.

10 Alvy Syahrin, Kesuksesan: Membuat Orang Suksses, http:alvyprofdr.blogspot.com/ 2010/11/notaris- pelaku-tindak-pidana-pasal-266.html, accessed on 10 November 2019 at $10.00 \mathrm{am}$. 
In order to be criminally, A notary must fulfill the following elements: committing a crime; has the ability to be responsible; by deliberate action or negligence; and there are no excuses. The jurisprudence of the Supreme Court (Supreme Court Decision No. 702 K / Sip / 1973, dated September 5, 1973) states: "Notary function only record / write down anything that you want and put forward by the parties facing the notary. There is no obligation for the notary to investigate materially nothing (matter case) is expressed by the client notary ". ${ }^{11}$

Notaries cannot be held criminal liability associated with the manufacture of the deed (partijnakten) that is based on false information, and cannot meet the crime of counterfeiting element formulation in Article 266 paragraph (1) in conjunction with Article 55 paragraph (1) of the Criminal Code. However, the notary can be held criminal liability against relaas deed or deed of officials (ambtelijke akten) if deliberate or negligent notary create a fake deed, to the detriment of the other party.

Based on interviews with Notary Junia Suryaningtiyas, SH., M. Hum., M.Kn Grobogan that the legal concept of criminal responsibility of the notary in the deed that is based on false information is a Notary Public is not a party to the agreement. In the notarized deed, a notary is an official in an agreement and put it on the deed. So if the parties give false information it is the responsibility of the parties themselves along the Notary does not know. ${ }^{12}$

\subsection{Effects against Deed Based On Fake Specification}

Applying the principle of presumption valid for notarization, then apply the provisions stated in article 84 of UUJN, that is concerned only has the strength of evidence as the deed under the hand no longer required, so that nullification is only a notary deed can be canceled or annulled by law. Legitimate principle presumptions related to notary deed with the irrevocable deed, an act is flawed, that is not competent notary to make physically deed, formal, and material, and not in accordance with the law of the notary deed. The principle cannot be used to assess the notary deed null and void, because the deed void by law considered to not have ever made.

Thus, for any reason, as noted above, the position of the notarial deed is:

- Can be canceled;

- Null and void;

- Have power verification as the deed under the hand;

- Canceled by the parties themselves; and

- Canceled by judicial decisions have binding legal force as a legitimate application of the principle of presumption.

${ }^{11}$ Alvy Syahrin, Kesuksesan: Membuat Orang Suksses, http:alvyprofdr.blogspot.com/ 2010/11/notaris- pelaku-tindak-pidana-pasal-266.html, accessed on 10 November 2019 at $10.00 \mathrm{am}$

${ }^{12}$ Results of interviews with Junia Notary Suryaningtiyas, SH., M. Hum., M.Kn, Grobogan, on December 13, 2019, 14:00 pm 
In connection with the notary deed cancelation, it should be noted the provisions of Article 84 UUJN. According to Article 84 UUJN that the violations committed notary against the provisions referred to in Article 16 paragraph (1) word i, article 16 no. (1) k, Article 41, Article 44, Article 48, Article 49, Article 50, Article 51, or Article 52 which resulted in a deed only has the strength of evidence as the deed under the hand or a certificate becomes null and void by the law may be grounds for the injured party to demand reimbursement of losses, damages, and interest to the notary.

Habib Adjie, stating that the sanctions against the notary is set at the end UUJN, namely Article 84 and 85 UUJN, there are two kinds: ${ }^{13}$

- Civil Punishment; This sanction in the form of reimbursement, indemnity or interest may be charged against a Notary should be based on a legal relationship between the Notary with the Parties to Notary, if there are those who feel harmed as a result of a Deed, the subject can sue civilly against a Notary, thus the demand reimbursement of expenses, damages and interest to the Notary is not based on an assessment or notch an evidence changed for violating Article 84 UUJN, but it can only be based on a legal relationship that exists or happens between the Notary with the client;

- Administrative sanctions; These sanctions include:

- Oral reprimand

- Written reprimand

- Temporary Scorse

- Respect dismissal

- Dishonorable discharge

UUJN specified in Article 842 (two) types of civil sanctions, if notary make do violation against certain articles and sanction chapters in the same case:

- Notary deed that has the strength of evidence as a deed under the hand; and

- The notarial deed null and void;

As a result of the notarial deed like that, then it can be a reason for those who suffered the loss to claim reimbursement, compensation, and interest to the notary.

The notary can be retire from his responsibility and accountability of law as a result of the deed that made defective, all the legal defects caused by the fault of others, or information or documentary evidence submitted by the client. Know the forms cause disability law that is not the fault notaries, such as the identity of asphalt or real or fake, like Identity Card, Family Card, Passport, Certificate of heirs, certificates, agreements, decrees, BPKB, Notification of a marriage, a birth certificate and etc. The document is generally a reference notary in the public service as a public official that commanded represent the country in an authentic deed. ${ }^{14}$

Information or statement the parties presented before a notary public is the base material for a notary to make the deed according to desire of the parties facing a notary. Without information or statements and wishes of the parties, the notary may

\footnotetext{
${ }^{13}$ Habib Adjie, Sanksi Perdata dan Administratif terhadap Notaris sebagai Pejabat Publik, Refika Aditama, Bandung, 2009, p. 91

${ }^{14}$ Sjaifurrachman and Habib Adjie, Aspek Pertanggungjawaban Notaris dalam Pembuatan Akta, Mandar Maju, Bandung, 2011, p. 26.
} 
Volume 6 Issue 4, December 2019

Nationally Accredited Journal,

Decree No. B/4130/E5/E5.2.1/2019

not make the deed. If there is information or statements allegedly false is entered into a notarial deed, it does not create the false certificates. For example, notary enter information into deed based on false identity documents (eg, fake IDs), does not mean notary insert false information into a notarial deed, as referred to in Article 264 paragraph (1) and Article 266 paragraph (1) of the Criminal Code. Materially, falsehood on it is the responsibility of the parties concerned, unless the notary knowing falsehood.

Based on interviews with Notary Junia Suryaningtiyas, SH., M. Hum., M.Kn Grobogan that the legal consequences of the notarial deed that is based on false information is if there is a demand in court for making notarial deed which is based perjury District Court usually decides that the certificate becomes invalid and its position as a deed under the hand (on the basis of evidence in court). ${ }^{15}$

\section{Closing}

\subsection{Conclusion}

Based on the above, then it can be given the following conclusion:

- Notary not constitute the parties are in agreement. In the notarized deed, a notary is an official in an agreement and put it on the deed. So if the parties give false information it is the responsibility of the parties themselves along the Notary does not know,

- If there is a demand in court for making notarial deed which is based perjury is usually the District Court ruled that the certificate becomes invalid and its position as a deed under the hand (on the basis of evidence in court),

\subsection{Suggestion}

- Suggested to all the parties in relation to such an authentic certificate issuance client parties and the Notary, so be careful and vigilant in making a deed for deed forgery that may cause harm to the people / society.

- Necessary to improve the quality of human resources involved in the effort, especially in institutions Law enforcement officials consisting of the police, prosecutors, and the judge so that the similarities judge in deciding a case at both the District Court, High Court and even the Supreme Court level.

\section{References}

[1] G.H.S. Lumban Tobing, 1982, Peraturan Jabatan Notaris, Erlangga, Jakarta

[2] Habib Adjie, 2009, Sanksi Perdata dan Administratif terhadap Notaris sebagai Pejabat Publik, Refika Aditama, Bandung, 2009

\footnotetext{
${ }^{15}$ Results of interviews with Junia Notary Suryaningtiyas, SH., M. Hum., M.Kn, Grobogan, on December 13, 2019, 14:00 pm
} 
[3] Kelsen, Hans, 2007, General Theory Of Law and State, Teori Umum Hukum Dan Negara, Dasar-Dasar IImu Hukum Normatif Sebagai IImu Hukum DeskriptifEmpirik, Alih Bahasa oleh Soemardi, BEE Media Indonesia, Jakarta

[4] Komar Andasasmita, 1981, Notaris Dengan Sejarah, Peranan, Tugas Kewajiban, Rahasia Jabatannya, Sumur, Bandung.

[5] Krisna Harahap, 2009, Konstitusi Republik Indonesia Menuju Perubahan ke-5, Grafiti Budi Utami, Bandung

[6] Lilik Mulyadi, 2007, Kekuasaan Kehakiman, Bina Ilmu, Surabaya

[7] Marthalena Pohan, 1985, Tanggung Gugat Advocaat, Dokter dan Notaris, Bina Ilmu, Surabaya

[8] Miriam Budiardjo, 1998, Dasar-Dasar IImu Politik, Gramedia Pustaka Utama, Jakarta

[9] Moeljatno, 1993, Perbuatan Pidana dan Pertanggung jawaban Dalam Hukum Pidana, Bina Aksara, Jakarta

[10] Sjaifurrachman dan Habib Adjie, 2011, Aspek Pertanggungjawaban Notaris dalam Pembuatan Akta, Mandar Maju, Bandung

[11] Sudikno Mertokusumo, 2004, Arti Penemuan Hukum Bagi Notaris, Renvoi

[12] Sri Endah Wahyuningsih, 2018, Model Pengembangan Asas Hukum Pidana Dalam KUHP Berbasis Nilai-Nilai Ketuhanan Yang Maha Esa, Fastindo, Semarang

[13] Zainudin Ali, 2009, Metode Penelitian Hukum, Sinar Grafika, Jakarta

[14] Alvy Syahrin, Kesuksesan: Membuat Orang Suksses, http:alvyprofdr.blogspot.com/ 2010/11/notaris- pelaku-tindak-pidana-pasal266.html accessed on 10 November 2019 at 10.00 am. 